\title{
pÿEstonian and Finnish Pupils Experiences of Religious Issues and Views on the Place of Religion in School
}

\section{Kallioniemi, Arto Juha Viljami}

2018

Kallioniemi , A J V , Schihalejev , O , Kuusisto , A \& Poulter , S 2018 , ' Estonian and Finnish pÿPupils Experiences of Religious Issues and Views on the Place of Religion in School ', Religion \& Education , vol. 45 , no. 1 , pp. 73-88 . https://doi.org/10.1080/15507394.2017.1355176

http://hdl.handle.net/10138/299405

https://doi.org/10.1080/15507394.2017.1355176

acceptedVersion

Downloaded from Helda, University of Helsinki institutional repository.

This is an electronic reprint of the original article.

This reprint may differ from the original in pagination and typographic detail.

Please cite the original version. 


\title{
Estonian and Finnish Pupils' Experiences of Religious Issues and Views on the Place of Religion in School
}

Kallioniemi, A. J. V., Schihalejev, O., Kuusisto, S. A. E. \& Poulter, S. M. 24 elokuuta 2017 julkaisussa : Religion \& Education.

\begin{abstract}
The study is part of the REDCo II study. The results are based on questionnaires. Altogether there were 988 participants from Finland $(\mathrm{N}=406)$ and Estonia $(\mathrm{N}=582)$. The main research questions were: What experiences do Estonian and Finnish pupils have regarding religious issues at school? What conceptions do Estonian and Finnish pupils have regarding the role of religion at school? And to what extent do different backgrounds factors (country, gender and age) explain different experiences and conceptions? The quantitative data were analysed by basic statistical analysis (including means, standard devolutions and t-tests).
\end{abstract}

Key words: religious education, Finland, Estonia, pupils' experiences

\section{Introduction}

Religious education (hence RE) and the role of religion in school has been a much-debated issue in recent years throughout Western societies ${ }^{1}$. Changes in the religious landscape in Europe have put pressure on developing a religious education that would be relevant both pedagogically and contentwise. When there is a great diversity of values and traditions in educational settings, it is essential to investigate the meaning and place of religions and worldviews in the lives of pupils. Only up-todate information enables the formulation of targeted aims designed for RE in school and the development of suitable approaches to achieve them. More than ever before, the functions of RE in society have been debated throughout Europe ${ }^{2}$ (Stocki 2015, 1).

Furthermore, the status of religion in the public sphere, such as in educational settings, has become a heated topic of discussion in many European countries. The need to re-evaluate the aims and practices of religious education, to support literacy on worldviews, and the acknowledgment of the diversity of religious and non-religious identities in the classroom have been deliberated in both scientific and policy literature internationally ${ }^{3}$. This article brings to international discussion a comparative perspective from two neighbouring countries, Finland and Estonia. These two countries are in a certain way very similar, but at the same time very different. 
There are many features in which Finland and Estonia are similar. Geographically, they are neighboring countries on two sides of the Gulf of Finland. Both the Estonian and the Finnish language belong to the Finno-Ugric language family. They also share a history of Lutheranism since the 16th century. Nowadays they are in very close connection to each other and many Estonians (app. 50,000) live in Finland ${ }^{4}$. Despite the close cultural relationship between the two countries today, their history and traditions are in some ways very different. Both countries have been shaped by the interventions of the former Soviet Union but due to different historical phases in the independence processes of the states, Estonia today can be characterized as a post-Soviet country, whereas Finland is a Nordic, post-welfare country. During the last 75 years the religious landscape as well as the religious education in schools in these two countries have taken on very different forms. This article focuses on Estonian and Finnish pupils' experiences of religion and the views they have about the place of religion in schools.

The REDCo project (Religion in Education. A Contribution to Dialogue or a Factor of Conflict in Transforming Societies of European Countries) aimed to study the role of religion in education with the goal of uncovering the way pupils perceive and deal with religious diversity. Along with other research approaches, a quantitative study was carried out in 2008 in eight European countries ${ }^{5}$. In 2012 a follow-up study (REDCo II) was made in twelve countries. New countries were involved in the study and the project reached not only countries involved in REDCo I, such as Finland and Sweden, but also countries outside of Europe, like South Africa and Mexico. In this article we draw on data from the REDCoII study. The questions addressed by the quantitative study were:

1. What role does religion play in pupils' life and their surroundings?

2. How do pupils see religion in school and what is the impact of religion in education?

3. What do pupils consider to be the impact of religions where dialogue and conflict are concerned?

4. Which are the similarities and differences between countries? ${ }^{6}$

\section{The religious landscape in Estonia}

Historically, Estonia has been religiously heterogeneous for many centuries: there has been a Lutheran population since the $16^{\text {th }}$ century, and a sizable Orthodox population since the middle of the $18^{\text {th }}$ century. There have also been other religious communities in Estonia, such as Jews, Muslims and Old Believers, who have been present from the $17^{\text {th }}-18^{\text {th }}$ centuries ${ }^{7}$. Before the Second 
World War Estonia could be called a Lutheran country (78\% of the population) with a sizable Orthodox minority (19\%) and several smaller denominations adding up to the country's religious heterogeneity, while $1 \%$ had no religious affiliation ${ }^{8}$. After almost 50 years of ideological statedriven anti-religious policies and practices during the Soviet era ${ }^{9}$, Estonia became an example of a secular country ${ }^{10}$.

The last census in 2011 shows that $29 \%$ of the population aged 15 and over defined their religious affiliation, whereas this share was lower among young people (14\% for 15-19 years old), compared to older age groups (44\% for 65 years and older). For the first time in history the most prevalent religion among the population aged 15 and older was Orthodoxy (16.2\%), followed by Lutheranism (9.9\%). 2.3\% of the population were affiliated to other Christian denominations and $0.8 \%$ to other religions ${ }^{11}$. These numbers say something about people's religious affiliation. Belonging to religious communities is far lower: according to the European Values Study ${ }^{12}$ in 2008, about $8 \%$ of the Estonian population said that they belonged to a religion. However, religion does not disappear from Estonia but rather changes its forms into non-organized fluid forms. Altnurme ${ }^{13}$ shows in her studies that the younger generation's religious self-understanding is shaped by a new sense of spirituality. Uibu ${ }^{14}$ argues that the new spirituality is on its way to become a mainstream form of religiosity. Different studies show that although Estonians are suspicious of many Christian truth claims, they are eager to believe in other things, such as "some sort of spirit or life force," animals and plants having a soul, in psychic healers and astrology, and so on ${ }^{15}$.

\section{The religious landscape in Finland}

Geographically, Finland is very close to Estonia but religious influence has been very different both on the societal and the personal levels in these two countries. As cultural and ideological pluralism has affected Finnish society during the past few years, religiosity in Finland has transformed into a notably more diverse form. The majority of Finnish people have been members of the Finnish Evangelical-Lutheran Church, and Finnish society has been very homogeneous regarding religious issues. Compared to many other European countries, Finland is formally still a Lutheran country: in 2015 about $73 \%$ of Finns belonged to the Lutheran Church, whereas $1.1 \%$ of the population belonged to the Finnish Orthodox Church. 1.6\% belonged to other registered religious communities, and $24.3 \%$ did not belong to any religious community ${ }^{16}$. However, the number of new religious movements is growing fast: in 2014 there were over 900 different religious groups and communities in Finland ${ }^{17}$. In addition, the number of people with a Muslim background is increasing: a rough 
estimate shows that there are over 60,000 Muslims in Finland ${ }^{18}$ and due to the great number of asylum seekers in 2016, the current size of the Muslim community might be considerably larger. According to the Pew Research Institute ${ }^{19}$, Finland will have 190,000 Muslims by the year 2050.

Despite the falling church membership rate, there is a growing interest in new religious movements and new forms of spirituality ${ }^{20}$. The characteristic feature of Finnish religiosity is that religion is increasingly becoming a private issue and religion is interpreted in very individualistic terms. Thus, Lutheranism, which earlier created a national and moral unity, can today be named "secular Lutheranism," which still affects the society in the form of cultural hegemony but does not give people their religious identities ${ }^{21}$. Despite the societal secularization and loss of institutional religiosity, post-secularization as the metamorphosis of religion and the growth of religious plurality can easily be recognized in Finnish society. As recent research shows, Finnish religiosity is becoming transformed, not disappearing. Religiosity today has been characterized as a matter of personal choice and empirical studies point to the fact that individual agency has become a central factor in constructing alternative religious identities and determining personal choices between different worldviews ${ }^{22}$.

\section{School as a public sphere}

While investigating pupil's experiences of religious issues in schools, it is important to note that schools are public institutions and a form of public space where the borderlines between public and private are negotiated ${ }^{23}$. In many Western countries, discussions about religion in education are politically and intellectually highly polarized and according to liberal-secularist thinking, religion is often acknowledged as a purely personal and private matter and religious expressions are widely considered inappropriate in public institutions. What is left unrecognized is the construction of the concepts of "public" and "private" that should be seen as ideological categories in which people are placed in disadvantaged positions ${ }^{24}$. By labeling people representing 'religious thinking' and drawing a strict line between secular and religious, the state manages to marginalize the voice of certain citizens.

The public debate about religion in Finland has focused on religious festivals and the right of individuals to be exempt from religious activities at school. Elsewhere in Europe, questions have been raised about the political role and visibility of religious symbols and traditions as part of the Western secular public space ${ }^{25}$. It is also interesting how multiculturalism and multicultural 
education have been used as an argument for very different political outcomes in relation to religion: to argue for purely secular education as well as for the right to faith-based schools. Therefore, it has often been argued that life in a pluralist society requires a secular, "empty" public sphere and an education free of strong value claims ${ }^{26}$. However, in this line of argumentation public educational space is considered to be socially, politically and epistemologically neutral. In the Finnish educational context this means an illusion that 'secular-Lutheranism' as a common belief and value basis can offer a safe and shared basis for equal education for all whereas in the Estonian context the rigidly secular or even anti-religious cultural platform forms the common education ground. In both cases, many hegemonic cultural expressions such as festivities including national and Lutheran elements are accepted as exceptions in school, and thus they keep non-reflected ideological connections alive and approved $^{27}$.

\section{Religious education in Estonia}

RE was reintroduced in Estonia together with the restoration of independence in the early 1990s along with heated discussions about its relevance, aims, and contents. The subject was heavily influenced by Finnish Lutheran RE, especially in the early 1990s when the first Estonian teachers were trained in Jyväskylä in Central Finland and the first textbooks were translated from Finnish into Estonian ${ }^{28}$. Also the first (advisory) syllabus of $\mathrm{RE}^{29}$ had a Christian focus. The subject was one of the most heated topics of discussion and it was accused of indoctrinating pupils. RE was a voluntary subject according to Estonian legislation, and its provision was dependent on schools' will to provide it or not - even for those who wished to study it ${ }^{30}$.

Heated debates about Christian-centred approaches in RE contributed to the development of Pille Valk's ${ }^{31}$ new non-confessional approach. Today new laws in Estonia give schools greater liberty and responsibility in the provision of RE. Schools may offer the subject at primary level, but they do not have to. In primary schools, the school's curriculum determines whether, how and under what conditions the subject is taught - as an elective subject, an extracurricular course, or a regular subject - provided that compliance with the national subject syllabus is ensured. In upper secondary schools, RE and national defence are two subjects the school must offer if at least one student wishes to study them. As in primary schools, the upper secondary schools can choose to make the subject obligatory, e.g. for classes specializing in the humanities. Among the aims of RE, tolerance 
and religious literacy are stressed, as well as recognition of and coping with prejudice and discrimination. The skills needed for dialogue are also developed in $\mathrm{RE}^{32}$.

\section{Religious education in Finland}

Finnish RE is a plural, nondenominational, but segregated, model of RE, organized according to the pupils' own religion, offering education in both Lutheran and Orthodox Christianity, secular ethics and eleven different minority religions. These minority religions are: Adventism, Bahá'í, Buddhism, The Lord's People (a protestant society), Islam, Judaism, Catholic Christianity, Hare Krishna, The Christian Community, Mormonism and The Free Church. For pupils who do not belong to any religious community, there is a specific subject called "secular ethics and life questions," which is a fully secular alternative subject to $\mathrm{RE}^{33}$. Despite the fact that the number of people who do not belong to any religious community has been decreasing, about $91 \%$ of comprehensive school students took part in Lutheran classes in 2014, whereas about 5\% attended secular ethics classes and $4 \%$ other minority $\mathrm{RE}^{34}$.

The Finnish way of organizing religious education at school is quite unique as it recognizes different religious or non-religious backgrounds of the pupils yet physically segregates them into separate teaching groups determined by the denominational groups. The current model was redefined in the 2003 reform of the Freedom of Religion Act to emphasize the positive freedom of religion. Although RE continued to be organized according to the pupil's religion, as a consequence of the 2003 reform, "confession" was changed to the expression "one's own religion" 35.

The general scope of Finnish RE is to look at religious and ethical dimensions of life from the viewpoint of the pupil's own development and also as a broader phenomenon in society. The main aim of RE is to develop a religious literacy that would help pupils understand their "own" religion as well as other religions from a critical perspective and to help them understand the ethical dimensions of life and life questions ${ }^{36}$. The Finnish RE model has been primarily justified by the need to recognize children's rights to their own religion and by claims that the model promotes the integration of minorities into Finnish society. However, as Finland becomes more diverse, and the need for a common understanding and dialogue between different worldviews increases, these arguments have been challenged ${ }^{37}$. Since the mix of languages, cultures and religions in Finland has increased and traditional religiosity has been challenged, evaluation and discussion of the way RE is implemented in schools is required. Recently some schools in Finland have developed a partly 
integrated, dialogical approach to religious and worldview education, with the particular aim of bringing pupils together to enhance learning between different worldviews ${ }^{38}$.

\section{METHOD AND SAMPLE}

The purposive non-probability sample ( $=988)$ analyzed here was collected with the REDCo II survey questionnaire in autumn 2012 from Estonia and Finland. In this sample there were 406 (41 $\%)$ participants from Finland and 582 from Estonia (59\%). The minority of participants were female $(\mathrm{N}=406,43 \%)$ and the rest were male $(\mathrm{N}=538,57 \%)$. The majority of respondents were 15 years old $(\mathrm{N}=507,52 \%)$, the second largest age-group were 16 years old $(\mathrm{N}=211,22 \%)$, and the third group were 14 years old $(\mathrm{N}=193,20 \%)$. There were also a few pupils who were under $14(\mathrm{~N}=12$, $1 \%)$ and also a few who were over 16 years of age $(\mathrm{N}=53,5 \%)$. For further analyses, two age groups were formulated: pupils under $16(\mathrm{~N}=712,72 \%)$ and pupils 16 years and over $(\mathrm{N}=251$, $28 \%)$. The majority of participants $(\mathrm{N}=563,57 \%)$ participated in religious education classes during the school year and only a few participants $(\mathrm{N}=418,43 \%)$ did not participate in such classes during the school year. There was a significant difference between countries: from the Finnish sample the vast majority of pupils $(\mathrm{N}=364,91 \%)$ participated in $\mathrm{RE}$ classes, whereas in the Estonia sample a little over a third $(\mathrm{N}=199,34 \%)$ participated in such classes.

The sample was analyzed by basic statistical analysis (including means, standard deviations and ttests).

This article aims to explore the following questions:

(1) What experiences do Estonian and Finnish pupils have regarding religious issues at school?

(2) What conceptions do Estonian and Finnish pupils have regarding the role of religion at school?

(3) How do the different background factors of pupils (country, gender and age) explain different experiences and conceptions?

\section{EXPERIENCES OF RELIGIOUS ISSUES AT SCHOOL}


There were six different statements in the assessment, where students were asked to express views on their experiences of religious issues in school using a 5-point scale. Students' means and standard deviations are shown in Table 1.

Table 1. Students' assessments concerning their experiences of religion in school. Frequencies, mean and standard deviations on a scale of 1 (strongly agree) to 5 (strongly disagree).

Finnish and Estonian pupils $(\mathrm{M}=2.2, \mathrm{SD}=1.0)$ evaluated clearly that at school they learn to have respect for everyone, whatever their religion; $66 \%$ of them put their estimations as 1 (strongly agree) or 2 (agree). They $(\mathrm{M}=2.3, \mathrm{SD}=1.1)$ also evaluated that at school they get knowledge about different religions; $65 \%$ of them put their estimation as 1 (strongly agree) or 2 (agree). Finnish and Estonian pupils $(\mathrm{M}=2.5, \mathrm{SD}=1.0)$ also felt that at school they have opportunities to discuss religious issues from different perspectives; $60 \%$ of them have put their estimations as 1 (strongly agree) or 2 (agree).

Pupils' gender differentiated their assessments. Male pupils $(\mathrm{M}=2.2, \mathrm{SD}=1.0)$ preferred that at school they would learn to have respect for everyone, whatever their religion, more than female pupils $(\mathrm{M}=2.3, \mathrm{SD}=1.0)$. The difference between genders is significant $\left(\mathrm{t}=2.8, \mathrm{p}=0.005^{* *}\right)$. Female pupils $(\mathrm{M}=2.7, \mathrm{SD}=1.1)$ also found topics about religions raised at school more interesting than male pupils $(\mathrm{M}=2.9, \mathrm{SD}=1.1)$. The difference is highly significant $(\mathrm{t}=4.0, \mathrm{p}=$ $\left.0.000^{* * *}\right)$. They $(\mathrm{M}=2.8, \mathrm{SD}=1.1)$ also preferred that learning about religions at school would help them to learn about themselves more than male pupils $(\mathrm{M}=3.0 \mathrm{SD}=1.1)$. The difference is significant $(\mathrm{t}=3.0, \mathrm{p}=0.002)$.

The country also differentiated pupils' concepts. Finnish pupils $(\mathrm{M}=1.9, \mathrm{SD}=0.8)$ estimated that at school they got knowledge about different religion clearly more than Estonian pupils did $(\mathrm{M}=$ 2.6, $\mathrm{SD}=1.1)$. Finnish pupils $(\mathrm{M}=2.0, \mathrm{SD}=0.9)$ also estimated that at school they learned respect for everybody whatever their religion clearly more than Estonian pupils did $(M=2.3, S D=1.1)$. They $(\mathrm{M}=2.3, \mathrm{SD}=0.8)$ also evaluated that at school they have opportunities to discuss religious issues from different perspectives more than Estonian pupils did $(\mathrm{M}=2.6, \mathrm{SD}=1.1)$. The differences are in all cases highly significant $(\mathrm{t}=10.4, \mathrm{p}=0.000 * * *, \mathrm{t}=4.7, \mathrm{p}=0.000 * * *$ and $\mathrm{t}$ $\left.=4.5, \mathrm{p}=0.000^{* * *}\right)$. Finnish pupils $(\mathrm{M}=2.9, \mathrm{SD}=1.0)$ estimated that they found topics about religions interesting at school more than Estonian pupils did $(\mathrm{M}=2.7, \mathrm{SD}=1.1)$. The difference is almost significant $\left(\mathrm{t}=2.4, \mathrm{p}=0.019^{*}\right)$. 
Pupils' age differentiated their concepts in many cases. Estimated totally, it can be seen that older pupils conceptions about religion in school are more positive that younger pupils'. This became evident when looking at the means of statements. Only in one statement "At school, I get knowledge about different religion" is there no statistically significate difference. Also in one statement "Learning about religion leads to conflicts in the classroom," younger pupils under 16 years of age $(\mathrm{M}=3.8, \mathrm{SD}=1.0)$ estimated more clearly that learning about religion leads to conflicts in the classroom than older pupils $(\mathrm{M}=3.6, \mathrm{SD}=1.0)$. The difference is significant $(\mathrm{t}=$ $3.2, \mathrm{p}=0.002 * *)$.

There is a tendency that older pupils have a more positive conception about religion in school. Older pupils, 16 years old or older $(\mathrm{M}=2.1, \mathrm{SD}=0.9)$, estimated that at school they learned to have respect for everyone, whatever their religion, clearly more than younger pupils under 16 years of age did $(\mathrm{M}=2.3, \mathrm{SD}=0.9)$. The difference is significant $(\mathrm{t}=3.0, \mathrm{p}=0.002 * *)$. Older pupils, 16

years old or older $(\mathrm{M}=2.2, \mathrm{SD}=1.0)$, also estimated that at school, they had opportunities to discuss religious issues from different perspectives more than younger pupils, under 16 years old $(\mathrm{M}=2.7,1.0)$. The difference is highly significant $\left(\mathrm{t}=5.6, \mathrm{p}=0.000^{* * *}\right)$. Older pupils, 16 years old or older $(\mathrm{M}=2.4, \mathrm{SD}=1.1)$, found topics about religions interesting at school more than younger pupils under the age of $16(\mathrm{M}=2.9, \mathrm{SD}=1.1)$. The difference is highly significant $(\mathrm{t}=7.1$, $\left.\mathrm{p}=0.000^{* * *}\right)$. Older pupils, 16 years old or older $(\mathrm{M}=2.7, \mathrm{SD}=1.1)$, clearly estimated that learning about religions at school helps them to learn about themselves more than younger pupils under the age of $16(\mathrm{M}=3.9, \mathrm{SD}=1.1)$. The difference is highly significant. $(\mathrm{t}=4.1, \mathrm{p}=0.000 * * *)$.

\section{The place of religion in school}

Pupils' assessments were analyzed using basic statistical indicators, including the means and standard deviations of their ratings. There were seven different statements in the assessment, in which students were asked to express their views on the place of religion in school, using a 5-point scale. Students' means and standard deviations are shown in Table 2.

Table 2. Students' assesments concerning religion's place in school. Frequencies, mean and standard deviations on a scale of 1 (strongly agree) to 5 (strongly disagree). 
Generally, students were very tolerant concerning the question of religion's place in school. Thus, the vast majority of students accepted the wearing of different religious symbols at school: concerning the wearing of discreet religious symbols at school (e.g. small crosses, etc. as a necklace) $79 \%$ of students put their estimation on scale alternatives 1 (strongly agree) or 2 (agree). When pupils were asked about wearing more visible symbols at school (e.g. headscarves) a little more than half of the students $(51 \%)$ either agreed or strongly agreed. It was interesting to see that students were noticeably more tolerant about accepting the wearing of discreet religious symbols than more visible symbols $\left(\mathrm{t}=18.1, \mathrm{p}=0.000^{* * *}\right)$. It is also interesting to note that only $20 \%$ of students estimated scale alternatives 1 (strong agree) or 2 (agree) when asked whether schools should provide facilities for students to pray in school, and $33 \%$ of students accepted the idea that voluntary religious services (e.g. school worship, prayer) can be a part of school life by putting their estimation on scale alternatives 1 (strongly agree) or 2 (agree).

Gender differentiated pupils' estimations. More female pupils $(\mathrm{M}=2.4, \mathrm{SD}=1.2)$ preferred that at school meals, religious food requirements should be taken into consideration than male pupils $(\mathrm{M}=$ $2.9, \mathrm{SD}=1.2)$. More female pupils $(\mathrm{M}=1.7, \mathrm{SD}=0.9)$ also agreed that students should be able to wear discrete religious symbols at school than male pupils $(\mathrm{M}=2.1, \mathrm{SD}=1.1)$. Furthermore, more female pupils were of the opinion $(\mathrm{M}=2.4, \mathrm{SD}=1.1)$ that students should be able to wear more visible symbols at school, than their male counterparts did $(\mathrm{M}=2.8, \mathrm{SD}=1.2)$. The differences between genders are in all cases highly significant $(\mathrm{t}=4.5, \mathrm{p}=0.000 * * *, \mathrm{t}=6.7, \mathrm{p}=0.000 * * *$ and $\left.\mathrm{t}=6.8, \mathrm{p}=0.000^{* * *}\right)$. This is in line with previous research ${ }^{39}$ that suggests that girls are more tolerant towards diversity than boys, and that it would seem that boys hold harsher, even more racist, views than girls do.

Country also differentiated pupils' estimations. Finnish pupils $(\mathrm{M}=2.1, \mathrm{SD}=1.2)$ clearly emphasized that at school meals, religious food requirements should be taken into consideration more than Estonian pupils did $(\mathrm{M}=3.0, \mathrm{SD}=1.1)$. The difference is highly significant $(\mathrm{t}=11.8, \mathrm{p}$ $=0.000^{* * *}$. The idea of using religious symbols also differentiated pupils in the two countries. Finnish pupils $(\mathrm{M}=2.2, \mathrm{SD}=1.2)$ were more of the opinion that students should be able to wear more visible religious symbols in school than Estonian pupils $(\mathrm{M}=2.8, \mathrm{SD}=1.1)$. The difference is highly significant $\left(\mathrm{y}=8.1, \mathrm{p}=0.000^{* * *}\right)$. Finnish pupils $(\mathrm{M}=2.2, \mathrm{SD}=1.1)$ were also more tolerant about the idea that students can be absent from school during their religious festivals $(\mathrm{M}=$ 2.5, $\mathrm{SD}=1.1)$. Finnish pupils $(\mathrm{M}=3.2, \mathrm{SD}=1.2)$, moreover, emphasized more than Estonian pupils $(\mathrm{M}=3.4, \mathrm{SD}=1.1)$ that schools should provide facilities for students to pray in school. The 
differences are highly significant in both cases $(\mathrm{t}=5.2, \mathrm{P}=0.000 * * *$ and $\mathrm{t}=4.5, \mathrm{p}=0.000 * * *)$. It was slightly surprising, however, that Estonian pupils $(\mathrm{M}=3.0)$ emphasized that voluntary religious services (e.g. school worship, prayers) could be a part of school life more than Finnish pupils did $(\mathrm{M}=3.3, \mathrm{SD}=1.2)$. The difference is highly significant $(\mathrm{t}=3.5, \mathrm{P}=0.000 * * *)$. This could be due to the fact that in Estonia religious schools were also included in the sample or that students in Estonia focused more on the word "voluntary" (in contrast to obligatory). The figures (1 and 2) illustrate the findings.

Figures

\section{Conclusions}

This article focused on examining the experiences of Estonian and Finnish pupils regarding the position of religious elements and symbols at school. More precisely, we have examined their experiences regarding religious issues at school, their conceptions on the role of religion at school, as well as the influence of various demographic background factors of pupils, namely their country of residence, gender, and age, in explaining the difference in pupils' experiences and conceptions. The findings illustrate a general openness towards worldview diversity and visibility of religions in the public sphere among pupils in both Estonian and Finnish settings. The pupils in both countries appreciate the value of gaining knowledge and learning to value different worldviews as well as gaining opportunities to discuss matters related to religion(s) from different perspectives in the school context.

When it comes to the points of variance between the two countries, Finnish pupils affirm more strongly than their Estonian counterparts that they learn about other religions and worldviews at school. Furthermore, the Finnish pupils are more in favor of learning about other worldviews and of gaining opportunities to discuss religion-related matters at school than Estonian pupils are. These findings are likely to be affected by the Finnish pupils' consistent involvement in worldview education instruction throughout the educational system in comparison to their Estonian counterparts, whose schools may not or more frequently have not dealt with religious and worldview issues at different phases of their compulsory education. The REDCo main study in Estonia (REDCo I) found that students who had studied RE were much more positive about their education on religious issues, were more tolerant about differences, and were more prepared to have a dialogue with representatives of different worldviews ${ }^{40}$. The study also found that students seem 
to prefer the status quo: they mainly appreciate the present practices in their school. Thus, children from schools which provide different options in their menu agree more with the need to take food requirements into consideration, whereas children with no experience of $\mathrm{RE}$ do, in contrast to children who are familiar with RE, not see the point of learning this subject ${ }^{41}$. The generally affirmative response to religion in Finland is reflected in the more positive attitudes to RE in Finnish schools, and, arguably, Finland is a less secular society than Estonia. Although religion is only one part of the culture in Finland, secularized form of Lutheranism ${ }^{42}$ is prevalent in every day life of the Finnish people, and Christianity still holds some visible presence in the societal sphere. By contrast, religion was more or less eradicated from Estonia during the Communist era, and today religion is still not a particularly visible part of Estonian the society. It can, moreover, be assumed that religious vocabulary is also widely absent from the environments in which Estonian children and youth grow up.

Concerning gender variance, the findings are in line with previous studies ${ }^{43}$ (that girls generally more interested in worldview-related matters than boys. In our findings, girls also had a stronger appreciation of the opportunities provided in RE classes to learn about themselves. Girls also tended to be more open towards the visibility and presence of religions in the school public sphere, along lines similar to those of previous studies (ibid.). Age variance analyses illustrated a more open position towards religious presence among the older pupils than the younger ones, again in line with previous findings from wider data analyses in the Finnish setting (ibid.). Older pupils also tended to appreciate the opportunities for learning about other views and for discussing religion- related matters than the younger pupils did. Finally, older pupils tended to find the topic area of worldview education more interesting and appreciate its value in learning about themselves.

The findings presented above illustrate an interesting view on the perceptions of pupils regarding the place of religion in the public sphere of the school in Finnish and Estonian settings, particularly from the viewpoint of the different histories concerning the public presence of religions in the societal landscape. What is similar in both of these settings is the prevalence of secular hegemony in the society. Reducing religion merely to an element of culture masks the deeper understanding of religion as multidimensional, dynamic and internally plural, besides disguising its connections to political and other wider value incentives ${ }^{44}$. In societal settings where religion is not discussed outside of worldview education classes, and secular hegemony forms the prevailing cultural understanding, other ways of thinking and being are judged on these foundations, and those labelled as 'Others' are excluded on multiple levels ${ }^{45}$. The secular majority's value position often stays 
invisible and unquestioned, which from the perspective of young people with a personal religious worldview is in many ways problematic ${ }^{46}$. Consequently, education concerning religions and worldviews has to be better contextualized within complex historical and societal processes ${ }^{47}$ including that of the vast number of youth whose worldview does not fit the secular norm.

\footnotetext{
${ }^{1}$ Robert Jackson, "European Institutions and the Contribution of Studies of Religious Diversity to Education for Democratic Citizenship" in Religion and Education in Europe: Developments, Contexts and Debates, edited by Robert Jackson, Siebren Miedema, Wofram Weisse \& Jean-Paul Willaime (Münster, Germany, Waxmann, 2009), 27-55; Robert Jackson, "European Developments" in Debates in religious education. Debates in subjects teaching, edited by Philip Barnes (New York, USA, Routledge 2012), 168-179.

${ }^{2}$ Kristiina Stoeckl "Knowledge about Religions and Religious Knowledge in Secular Societies: Introductory Remarks to the Future of Religious Education in Europe" in The Future of Religious Education in Europe, edited by Kristina Stoeckl and Roy Oliver (Florence: European University Institute, 2015), 1-6.
}

${ }^{3}$ Robert Jackson, Signposts': Policy and Practice for Teaching about Religions and Non-Religious Worldviews in Intercultural Education (Strasbourg, Germany: Council of European Publishing, 2014); Siebren Miedema, "Coming Out Religiously!" Religion, the Public Sphere and Religious Identity Formation. Religious Education 109 (4), (2014), 362-377; Jack L. Seymour, Editorial: "Religion and Schools; Religion and Public Life", Religious Education, 109 (4), (2014): 359-360

${ }^{4}$ Statistics Finland. Suomen virallinen tilasto (SVT): Väestörakenne. ISSN=1797-5379. (Helsinki: Tilastokeskus, 2015).. http://www.stat.fi/til/vaerak/index.html (accessed September 13, 2016).

${ }^{5}$ Teenagers' perspectives on the role of religion in their lives, schools and society. A European study. editen by Pille Valk, Gerdien Betram-Troost, Markus Friederici, and Céline Beraud (Münster/ New York / München / Berlin: Waxmann Verlag GmbH, 2009).

${ }^{6}$ Gerdien Bertram Troost, Olga Schihalejev and Sean Neill, Religious Diversity in Society and School: Pupils' Perspectives on Religion, Religious Tolerance and Religious Education. Religious Education Journal of Australia, 30 (1), (2014), 17-23.

${ }^{7}$ Olga Schihalejev, "Religious Education at Schools in Estonia" in Religious Education at Schools in Europe, edited by Martin Rothgangel, Geir Skeie and Martin Jäggle, (Vienna, Austria: Vandenhoeck \& Ruprecht, 2014). 75-104.

${ }^{8}$ Riigi Statistika Keskbüroo, Rahvastiku koostis ja korteriolud. 1.III 1934 rahvaloenduse andmed. Vihk II = Composition démographique de la populationn et logements. Données du recensement e 1. III 1934. Vol. II. (Tallinn, Estonia: Riigi trükikoda, 135).

9 Atko Remmel and Marko Uibu, Outside Conventional Forms: Religion and Non-Religion in Estonia. Keynote lecture on the Nordic Conference on Religious Education, Tartu, 2015.

${ }^{10}$ Peter Berger, Davie Grace and Effie Fokas, Religious America, Secular Europe? A Theme and Variations. (Aldershot, England ; Burlington, VT: Ashgate Publishing, 2008); Detlef Pickel \& Olof Müller "Differentiated Secularization in Europe: Comparative Results" in The Social Significance of Religion in the Enlarged Europe: Secularization, Individualization and Pluralization edited by Detlef Pickel., Olaf Müller \& Gert Pickel. (Farnham: Ashgate Publishing, 2012). 229-256.

${ }^{11}$ Population and Housing Census 2000 and 2011, www http://pub.stat.ee/pxweb.2001/I_Databas/Population_Census/databasetree.asp. (accessed September 13, 2016). 
${ }^{12}$ European Values Study, European Values Study 2008: Integrated Dataset (EVS 2008). GESIS Data Archive, (Cologne. ZA4800 Data file Version 3.0.0, doi:10.4232/1.11004, 2011)

${ }^{13}$ Lea Altnurme, Changes in mythic patterns in Estonian religious life stories. Social Compass, 58 (1), (2011), 77-94.

${ }^{14}$ Marko Uibu, Re-Emerging Religiosity: The Mainstreaming of the New Spirituality in Estonia. Journal of Baltic Studies 47 (2), (2016), 257-274.

${ }^{15}$ Atko Remmel and Marko Uibu, 2015.

${ }^{16}$ Statistics Finland, 2015. Arto did you have a direct URL-address for these?

${ }^{17}$ Statistics Finland, 2015.

${ }^{18}$ Statistics Finland, 2015.

19 Pew Research Institute. 2015. Religious Composition by Country 2010-2050. http://www.pewforum.org/2015/04/02/religious-projection-table/

${ }^{20}$ Terhi Utriainen, Marcus Moberg, Måns Broo and Tommy Ramstedt, “Diversification,

Mainstreaming, Commercialization, and Domestication: New Religious Movements and Trends in Finland" in Handbook of New Nordic Religions, edited by James R. Lewis and Inga Bårdsen.

Tøllefsen (Leiden, The Netherlands: Brill, 2015), 141 - 157.

21 Anna-Leena Riitaoja, Saila Poulter and Arniika Kuusisto, Worldviews and Multicultural Education in the Finnish Context: A Critical Philosophical Approach to Theory and Practices. Finnish Journal of Ethnicity and Migration, 5 (3) (2010), 87-95.

22 Arniika Kuusisto, Growing up in Affiliation with a Religious Community: A Case Study of Finnish Adventist Youth. Research on Religious and Spiritual Education, 3. (Münster, Germany: Waxmann., 2011); Anne-Birgitta Pessi, "Privatized Religiosity Revisited: Building an Authenticity Model of the

Individual-church Relations." Social Compass 60 (1) (2013), 3-21.

${ }^{23}$ Saila Poulter, "Uskonto julkisessa tilassa: koulu yhteiskunnallisuuden näyttämönä" [Religion in the Public Sphere. School as a Societal Arena], Kasvatus, 44 (22), (2013), 162-176.

24 Nancy Fraser, "Politics, culture, and the public sphere: toward a postmodern conception" in Social Postmodernism: Beyond Identity politics, edited by Linda Nicholson and Steven Seidman (Cambridge, United Kingdom: Cambridge University Press, 1995), 287-312; Jürgen Habermas, 1989. Structural Transformation of the Public Sphere. An Inquiry into a Category of a Bourgeois Society. (Oxford, United Kingdom: Polity Press, 1989).

25 Jürgen Habermas, Between Naturalism and Religion: Philosophical Essays (Oxford, United Kingdom: Polity Press, 2008); David Coulby and Evie Zambeta,'Intercultural education, religion and modernity", Intercultural education 19 (4) (2008), 293-295.

${ }^{26}$ Saila Poulter, Anna-Leena Riitaoja and Arniika Kuusisto, "Thinking Multicultural Education 'Otherwise': From a Secularist Construction Towards a Plurality of Epistemologies and Worldviews." Globalisation, Societies and Education 14 (1), (2016), 68-86. doi: http://dx.doi. org/10.1080/14767724.2014.989964.

27 Kimmo Kääriäinen, Kati Niemelä and Kimmo Ketola. Religion in Finland. Decline, Change and Transformation of Finnish Religiosity. Publication 54. (Tampere, Finland: Church Research Institute, 2005, 168).

${ }^{28}$ E.g. Simo Heininen, Marja-Liisa Mauranen, Matti Mäkituuri and Lauha Peltola, Kiriku ajalugu ja teave. (Keuruu, Finland : Otava, 1990); Ulla Kankaanpää, Riitta Nisonen and Markku Töllinen, Hea Karjane 1: Õpetaja raamat. (Tallinn, Estonia: EELK Pühapäevakooli Ühendus, 1994)

${ }^{29}$ Sirje Kiivit, Meelis Kond, Mare Kraav, Üldhariduskooli programmid. Usuõpetus. (Tallinn, Estonia: Haridusministeerium, 1991;

${ }^{30}$ Pille Valk, "Religious Education in Estonia" in Religion and Education in Europe.

Developments, Contexts and Debates edited by Robert Jackson, Siebren Miedema, Wolfgram 
Weisse and Jean-Paul Willaime. Religious diversity and education in Europe, Vol. 3 . (Münster, Germany: Waxmann Verlag GmbH, 2009), 159-180; Olga Schihalejev "Shifting borders in religious education in Estonia" in Crossings and Crosses Borders, Educations, and Religions in Northern Europe edited by Jenny Berglund, Tuomas Lundén, and Peter Strandbrink (Berlin, Germany: De Gruyter 2015), 85-104.

${ }^{31}$ Pille Valk, Eesti kooli religiooniõpetuse kontseptsioon [The conception of RE for Estonian schools]. Doctoral dissertation. (Tartu, Estonia: Tartu University Press, 2003).

${ }^{32}$ Olga Schihalejev 2015.

${ }^{33}$ Arto Kallioniemi and Martin Ubani "Religious Education in Finnish school system" in Miracle of Education: The Principles and Practices of Teaching and Learning in Finnish Schools edited by Hannele Niemi, Auli Toom and Arto Kallioniemi (Rotterdam:, The Netherlands: Sense Publications, 2012), 177-188.

${ }^{34}$ Statistics Finland, 2015. Tähän www-sivu!

${ }^{35}$ Arto Kallioniemi and Martin Ubani 2012.

${ }^{36}$ National Core Curriculum for Basic Education. Finnish National Board of Education. (Helsinki, Finland: Hakapaino), 2004.

${ }^{37}$ Harriet Zilliacus, Supporting student's identities and inclusion in minority religious and secular ethics education: a study on plurality in the Finnish comprehensive school (Helsinki, Finland: University of Helsinki, 2014).

${ }^{38}$ Vesa Åhs, Saila Poulter and Arto Kallioniemi, Encountering worldviews: Pupil perspectives on integrated worldview education in a Finnish secondary school context. Religion and Education. 2016. DOI:10.1080/15507394.2015.1128311; Preparing for the world of diverse worldviews: parental and school stakeholder views on integrative worldview education in a Finnish context. British Journal of Religious Education. 2017. DOI: 10.1080/01416200.2017.1292211.

${ }^{39}$ Kristiina Holm Ethical, Intercultural and Interreligious Sensitivities: A Case Study of Finnish Urban Secondary School Students, (Münster, Germany: Waxmann, 2012); Arniika Kuusisto, Elina Kuusisto, Kristiina Holm and Kirsi Tirri. Gender variance in interreligious sensitivity among Finnish pupils. International Journal for Children's Spirituality 19 (1) (2014). 25-44. ${ }^{40}$ Olga Schihalejev, From Indifference to Dialogue? Estonian Young People, the School and Religious Diversity. (Münster, Germany: Waxmann Verlag GmbH, 2010).

41 Olga Schihalejev, "Religious education - is it something to be afraid of?" in Regional Development in Estonia editen by Ene Narusk, (Tallinn, Estonia: Statistikaamet, 2012), 135-150.

${ }^{42}$ Anna-Leena Riitaoja, Saila Poulter and Arniika Kuusisto 2010; Saila Poulter, Anna-Leena Riitaoja and Arniika Kuusisto, 2016.

${ }_{43}^{43}$ Arniika Kuusisto, Elina Kuusisto, Kristiina Holm and Kristi Tirri 2014.

44 Saila Poulter, Kansalaisena maallistuneessa maailmassa. Koulun uskonnonopetuksen yhteiskunnallinen tehtävä. [Citizenship in Secular Age. The Civic Aim of Religious Education] Suomen ainedidaktisen tutkimusseuran julkaisuja, 5. (Helsinki, Finland: Suomen ainedidaktinen tutkimusseura, 2013), Pille Valk, Gerdien Betram-Troost, Markus Friederici, and Céline 2009; Arniika Kuusisto, Saila Poulter and Arto Kallioniemi, Finnish Pupils' Views on the Place of Religion in School, Religious Education, 111 (2) (2016) 1-18, http://dx.doi.org/10.1080/00344087.2016.1085237; Liam Gearon, The Counter Terrorist Classroom: Religion, Education, and Security, Religious Education, 108 (2), (2013). 129-147.

${ }^{45}$ Saila Poulter, Anna-Leena Riitaoja and Arniika Kuusisto, 2016.

${ }^{46}$ Arniika Kuusisto, Saila Poulter and Arto Kallioniemi 2016. 
${ }^{47}$ Arniika Kuusisto, Saila Poulter and Arto Kallioniemi 2016; Arniika Kuusisto \& Liam Gearon, L. (forthcoming). The Life Trajectory of the Finnish Religious Educator. An article manuscript. 